\title{
Criminal Skins: Tattoos and Modern Architecture in the Work of Adolf Loos
}

\section{Citation}

Canales, Jimena and Andrew Herscher. 2005. Criminal skins: Tattoos and modern architecture in the work of Adolf Loos. Architectural History 48:235-256.

\section{Published Version}

http://www.sahgb.org.uk/index.cfm/display_page/Publications

\section{Permanent link}

http://nrs.harvard.edu/urn-3:HUL.InstRepos:3210516

\section{Terms of Use}

This article was downloaded from Harvard University's DASH repository, and is made available under the terms and conditions applicable to Other Posted Material, as set forth at http:// nrs.harvard.edu/urn-3:HUL.InstRepos:dash.current.terms-of-use\#LAA

\section{Share Your Story}

The Harvard community has made this article openly available.

Please share how this access benefits you. Submit a story.

Accessibility 


\section{Criminal Skins: Tattoos and Modern Architecture in the Work of Adolf Loos}

by JIMENA CANALES and ANDREW HERSCHER

If someone who is tattooed dies in freedom, then he does so a few years before he would have committed murder.

Adolf Loos, Ornament and Crime (1908)

\section{INTRODUCTION}

Adolf Loos's famous essay, 'Ornament and Crime', decisively linked unornamented architecture with the culture of modernity and, in so doing, became one of the key formulations of modern architecture. ${ }^{1}$ To a great extent, the essay's force comes from arguments drawn from nineteenth-century criminal anthropology. Nevertheless, Loos's work has been consistently understood only within the context of the inter-war avantgardes. In the 1920s, Le Corbusier was particularly enthusiastic in bringing Loos's work to the fore, thereby establishing its future reception. ' 'Ornament and Crime' became an essential catalyst for architecture's conversion away from the historicism of the nineteenth century to modernism. At the turn of the century, Loos's essay already foreshadowed the white abstraction of 'less is more' architecture and the functionalist rigour of the International Style which would dominate the twentieth century. While these later movements abandoned the essay's scientific basis as it became outdated, they nevertheless wholly embraced, incarnated and perpetuated the formal proscriptions of 'Ornament and Crime'. In this way they prolonged the ineffable presence of nineteenth-century criminal anthropology.

Violence against ornament characterized nineteenth-century critiques besides Loos's. Nietzsche, for example, condemned 'decorative culture' in his renowned 'On the Uses and Disadvantages of History for Life'. For him 'adornment' was a disease whose symptoms plagued historicist architecture just as much as they did contemporaneous historiography. ${ }^{3}$ Nietzsche's parallel between ornament in architecture and that in historiography can be extended to modern architecture; by overlooking specific sites of knowledge production, historians of modernism have ornamentalized and effaced its extensive reliance on criminal anthropology.

Recently scholars have started to recover parallels between Loos's comments on tattoos and the work of the criminal anthropologist Cesare Lombroso, yet these authors continue to ignore the constitutive role of criminal anthropology in Loos's theorization of modern architecture. ${ }^{4}$ This essay therefore details Loos's debt to criminal 
anthropology, by analyzing his arguments drawn from its 'Italian school' and by bringing to light the role of Haeckel's biogenetic principle and theories of atavism and degeneration. It will analyze how Loos's work fits into contemporaneous scientific theories of ornament (Darwin, Haeckel, Nordau and Lombroso), museological arrangements, and the prevailing aesthetic theories of ornamentation, as advanced by Gottfried Semper and Alois Riegl. It is through the concept of tattoos that all of these discourses merged, and therefore this concept will direct the argument of this essay.

In consequence the reading of 'Ornament and Crime' offered here will focus on Loos's extension of criminal anthropology's classificatory gaze from the human body to its material prostheses, the Gebrauchsgegenstande, or objects of everyday use. The proscriptions advanced in 'Ornament and Crime' for application to the entire field of material culture were derived from the taxonomy of marks established by criminal anthropology for distinguishing between normal and deviant bodies. The unornamented architecture and applied art called for by Loos were thus not only the 'liberating' equipment of modern life but also a means by which to distinguish those individuals, communities, nations, and races capable of participating in that life. Accordingly, to the many functions of unornamented architecture and applied art already enumerated by modernism's theoreticians and historians, should be added the function of marking social, political, and cultural differences, and thereby endowing those differences with a palpable and material existence.

\section{LOOS AND CRIMINAL ANTHROPOLOGY}

Loos's first 'battle cry against ornament' ${ }^{5}$ appeared in 'The Luxury Vehicle', one of a series of articles written on the occasion of the Vienna Jubilee Exhibition of 1898. Instead of considering ornament as it had traditionally been understood, as an inherent feature of any artistic work, Loos saw it as a signifier of that work's level of cultural development. He insisted that carriages should be classified according to their degree of ornamentation. He relegated American carriages to an 'earlier' phase of development because they were ornamented with acanthus leaves. ${ }^{6}$ Loos explained his 'history of civilization' in this essay on the exhibition:

Let us briefly review a few chapters of the history of civilization. The lower the cultural level of a people, the more extravagant it is with its ornament, its decoration. The Indian covers every object, every boat, every oar, every arrow with layer upon layer of ornament. To see decoration as a sign of superiority means to stand at the level of the Indians. ${ }^{7}$

For him, the ornaments on the American carriages showed 'the Indian in them'. ${ }^{8}$

The triad of taste, race, and civilization was not exclusive to Loos's writings. These connexions were common in natural history and in the scientific discourse on man. Although scholars have frequently ignored this aspect of Darwin's work, taste occupied an essential role in his theory of evolution, where it was singularly important in determining evolutionary pathways. ${ }^{9}$ Different races, Darwin explained, had different tastes, and these differences in taste, in turn, made races differ further, since mates considered the most attractive would be chosen first. Belonging to a certain race was therefore tantamount to exercising a certain taste, and vice versa. Darwin believed in 
the possibility that taste 'may in the course of time become inherited', for this would explain each race's 'own innate ideal of beauty'. ${ }^{10}$

Darwin did not only invoke taste to explain the emergence of different races, but also used it to explain other cultural products, even artistic and architectural ones. Just as certain drakes preferred black and white ducks over highly ornamented ones, so civilized man preferred 'the Jupiter or Apollo of the Greeks' to the 'hideous bas-reliefs on the ruined buildings of Central America'. ${ }^{11}$ In Darwin's theory of evolution, race, taste and civilization had already been linked together, scientifically. As the century progressed these connexions would be re-examined both from within the sciences and from aesthetic and architectural theory, sources from which Loos drew selectively. ${ }^{12}$

In an article on women's fashion, published a few months after that on 'Luxury Vehicles', Loos repeated his argument about ornament but extended it to include women, Papuans, and criminals. Here, however, he began to present ornament as a mark of criminality, as well as of primitiveness, noting that, 'the Papuan and the criminal ornament their skin'. The excessive ornamentation of women's clothing '[demonstrates] to us that the woman has fallen behind sharply in her development in recent centuries'. ${ }^{13}$ As women advance in their development, Loos predicted, their fashion will follow men's, and its elaborate ornamentation 'will disappear'. Papuans, alongside women, recurred throughout his work as a preferred example, most likely because they represented Germany's late nineteenth-century colonial adventure in New Guinea. ${ }^{14}$

Loos saw women's fashion currently as being dictated by the prostitute and by the criminal. ${ }^{15}$ For this reason, he continued, the best female fashion manuals were the articles in the Penal Code dealing with sexual crimes: 'The sentences meted out according to paragraphs 125 through 133 of our Penal Act are the most reliable fashion journal. ${ }^{\prime 16}$ For him, changes in women's fashion corresponded directly with changes in sexual crimes: in the 1870 s and early 188 os fashion and crime alike demanded voluptuosity and flagellation, as exemplified in the novels and poetry of SacherMasoch, Catuelle Mendès and Armand Silvestre; then, in the later 1880s and early 1890s, fashion turned to the round and ripe femininity of 'le cul de Paris'; and finally, at the turn of the century, the 'cry for youthfulness rang out', making the child-woman the coveted object of desire. ${ }^{17}$ His correlation of ornament with the feminine, and alongside this the criminal, primitive and sexual, continued to pervade his work as it developed. 'In the final analysis', Loos wrote, 'women's ornament goes back to the savage, it has erotic significance. ${ }^{18}$

Loos infantilized, orientalized, feminized and criminalized specific Austrian and German architects and designers who employed ornament. In a private publication, which served as an architectural guide to his own work, he explained in this way how Secessionist architects such as Josef Olbrich, Henry Van der Velde and Josef Hoffman were still producing intensely decorated architecture. ${ }^{19}$ While he considered himself to be a thoroughly modern man, these ornament-makers belonged to a different era:

Only people, that, although they were born in the present, actually live in a past century, like women, peasants, orientals (including the Japanese), mutilated brains like tie and rug designers, create even today new ornaments, of the same value as antique ones. $^{20}$ 
In this article, Loos targeted applied art in general, but in particular current state employees of cultural institutions, 'barbarians of culture' who were forced by their 'Indian furour' to compulsively ornament. He appreciated ornament in 'the old master or the new oriental', where it 'emerged directly from their soul', but its existence in Austria and in Germany in his own time was a dangerous atavism. He reiterated his characteristic line: 'The incapacity of our culture to create a new ornament is a sign of its greatness. The evolution of humanity goes hand in hand with the disappearance of ornaments in every-day objects. ${ }^{21}$ In 'Architecture' (1910), Loos extended this criticism to the entire architectural profession, contrasting its ornamented creations with traditional 'peasant homes', which escaped his chastising.

Primitives, like children, criminals, degenerates and women, Loos wrote, were seized with an inescapable urge to ornament themselves and their surroundings. Yet as man evolved, he argued, the urge for ornament finally disappeared. In 'Ornament and Crime', Loos stated his famous dictum: 'I made the following discovery, which I passed on to the world: the evolution of culture is synonymous with the removal of ornamentation from objects of everyday use.'22 The 'discovery' that Loos claimed for himself, of focusing on decrease in ornamentation as a mark of evolution's forward march, was already present in the On the Origin of Species, and its association with criminality can be traced to the Italian criminologist Cesare Lombroso.

\section{LOMBROSO: ORNAMENT IN CRIMINAL ANTHROPOLOGY}

Lombroso was well-known in the late nineteenth century for advocating a biological explanation of crime and for indicting sociological theories of criminality. According to him, the biological signs of criminality were readily visible. Material 'stigmata', both on the body and produced by the body, betrayed the criminal. ${ }^{23}$ His L'Uomo Delinquente, first translated into German in 1887 and reprinted several times, was extremely popular, not only in turn-of-the-century Viennese scientific and medical circles but also in a much wider context. ${ }^{24}$ The work of Loos, Lombroso and his disciple Max Nordau often appeared side by side, indicating that they addressed the same readership. References to Lombroso and to Nordau, for example, abound in the same publications in which Loos's work appeared: in the Viennese newspaper Neue Freie Presse, in Karl Kraus' journal Die Fackel, and in the Viennese architectural magazine Der Architekt. Loos's private correspondence reveals that he followed the work of Nordau closely, read the latest medical and biological research, and addressed similar audiences. ${ }^{25}$

An important object common to both criminology and aesthetic and architectural theory was the tattoo. ${ }^{26}$ The ornament and the tattoo were established as parallel forms of 'free beauty' in Kant's aesthetic theory, written at the very moment when tattoos were 'discovered' in Europe, after Captain Cook's expeditions to the South Seas; for Kant the connexion between ornament and tattoo was based on each element's 'uselessness', rather than on its primitivism. ${ }^{27}$ A key change in the understanding of tattoos and theories of ornamentation had occurred by the middle of the nineteenth century. Darwin and others were struck by the 'primitive's' urge for tattoos. ${ }^{28}$ Naturalists, who increasingly believed the early stages of the development of 'man' 

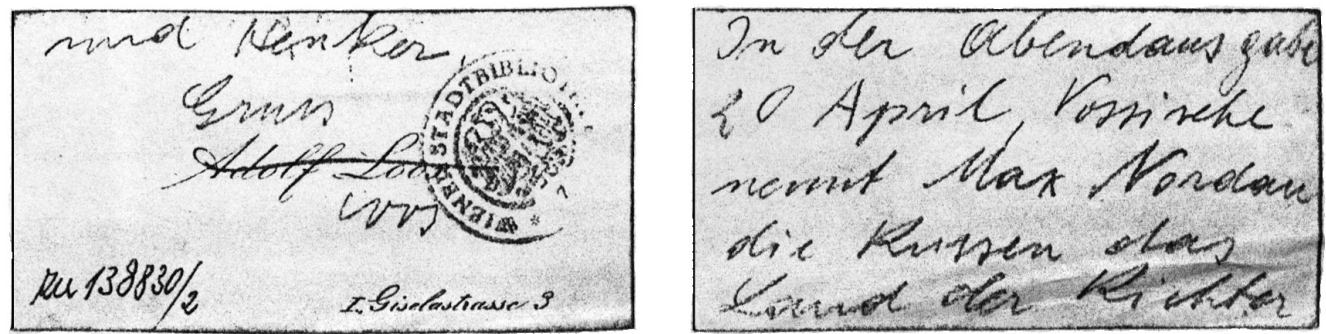

Fig. 1. Loos's presentation card, mentioning how Max Nordau referred to Russia as the 'Land der Richter und Henker'. This was a variation on the phrase used to describe Germany as the 'Land der Dichter und Denker' (Wiener Stadt- und Landesbibliothek, 138830/2)

could be found in 'existing semi-civilized and savage nations', drew on and contributed to ongoing discourses that designated usage of ornament in general, and of tattoos in particular, as primitive. 'That [savages] have a passion for ornament', Darwin wrote, 'is notorious.' He went on to describe how they 'deck themselves with plumes, necklaces, armlets, ear-rings ... and paint themselves in the most diversified manner.' 'Ornaments', he concluded, 'are highly valued' in 'all barbarous races'.$^{29}$ The primitive's predilection for ornament was so frequently noted that another writer defined 'savages' as those who could 'not distinguish the superfluous from the necessary'.$^{30}$

While working with current associations of ornamentation and primitiveness, Lombroso added a third factor, criminality. According to him, the criminal and the primitive converge primarily through their use of one particular type of ornament, namely the tattoo. In L'Uomo Delinquente, Lombroso combined what had up to then been two separate strands of the literature on tattoos. The first, most significant body of literature that he consulted dealt with tattoos in primitives, from an anthropological perspective. ${ }^{31}$ The second strand in his study of tattoos drew on the work of criminologists. ${ }^{32}$ Lombroso merged these different interpretations of tattoos into one, arguing that - because of their atavistic nature - the criminal's urge for ornament was equivalent to the primitive's. ${ }^{33}$

In 'Ornament and Crime', Loos followed Lombroso in linking criminals with primitives by means of the tattoo. Using the characteristic logic of the 'Italian school' of criminology, he wrote:

A modern person who is tattooed is either a criminal or a degenerate. There are prisons in which eighty percent of the criminals are tattooed. Tattooed persons who are not in prison are either latent criminals or degenerate aristocrats. If someone who is tattooed dies in freedom, then he does so a few years before he would have committed murder. ${ }^{34}$

Loos explained how 'the modern person who, due to an inner urge, marks walls with erotic symbols is either a delinquent (Verbrecher) or a degenerate (Degenerierter)' ${ }^{35}$ Like Lombroso he saw these marks as an unequivocal sign of evolutionary development: 'One can measure the cultural development of a country by the amount of graffiti on the bathroom walls.' In children and primitives this urge was understandable, but 'what is natural in the Papuan and the child is a sign of degeneration (Degenerationserscheinung) in modern man'. ${ }^{36}$ 

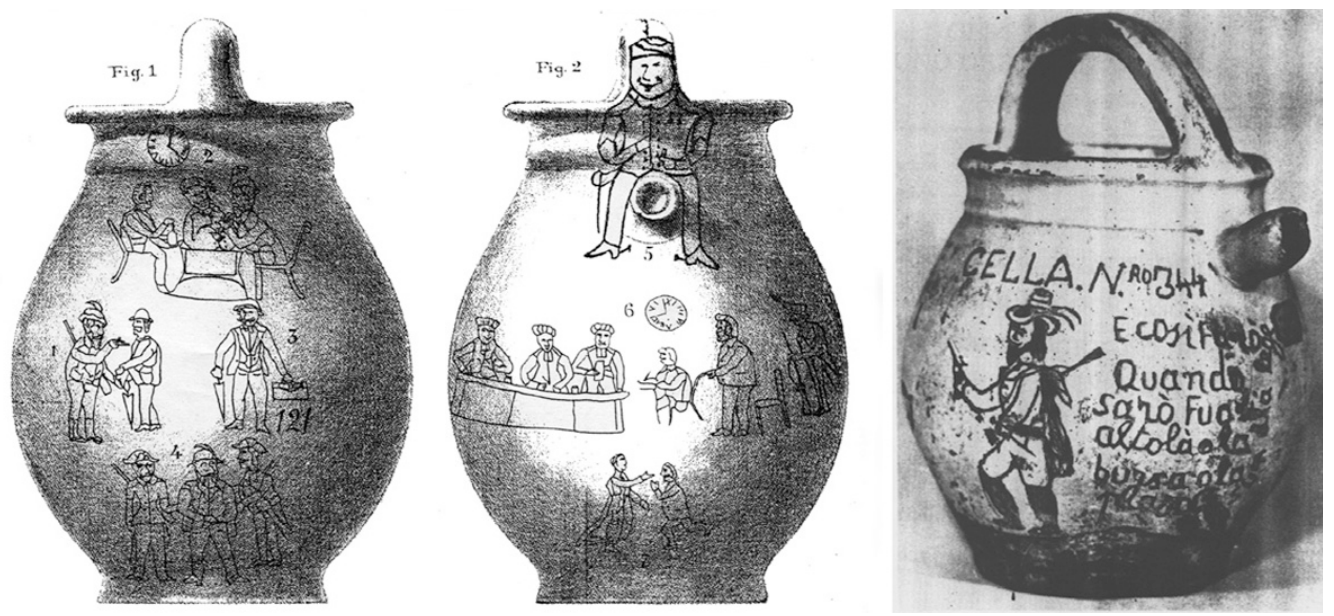

Fig. 2. Criminals' drawings on pottery from Cesare Lombroso, Prison Palimpsests, Table 2, on the left. Pottery from the Museo di antropologia criminale in Turin, on the right (as reproduced in Mariacarla Gadesbusch Bondio, Die Rezeption der kriminalanthropologischen Theorien von Cesare Lombroso in Deutschland von 1880-1914 (Husum, 1995), p. 291)

THE PHYSIOGNOMY OF MATERIAL CULTURE

Lombroso's focus on the tattoo as the distinguishing mark of the criminal and the primitive was part of his larger interest in other marks left by criminals. He obsessively investigated criminal sketches and drawings. Although historians have frequently described Lombroso's work on the physiognomy of the criminal, his extension of this same physiognomic logic from the criminal body to criminal 'culture' - graffiti, writings, paintings, jargon, and so on - has received almost no attention. At the time, however, his physiognomic study of the atavistic material culture of criminals was highly influential, founding a new mode of art criticism based largely on criminal anthropology. The use of natural history and criminology in the analysis of material culture characterized a school of art criticism that focused variously on evolution, degeneration, atavism and criminality. The most well-known proponent of this type of art criticism was Max Nordau, who considered art ranging from Monet to Zola as the result of these artists' physical degeneracy. While historians have frequently focused on the work of Nordau as an extreme example of degeneration theories in art, arguments drawn from natural history and evolution were commonplace in turn-of-the-century architectural criticism. Loos's writings on architecture and fashion fit neatly within this discourse. ${ }^{37}$

With the tattoo's ambiguous status as both on the body yet external to it, Lombroso's reading of the tattoo extended the boundaries of a physiognomic science that had only focused on the body to include material culture in general. In Palimsesti del Carcere, a book dedicated to cataloguing criminal inscriptions, Lombroso observed how the 'walls, drinking-vessels, planks of the prisoners' beds, margins of books, medicine wrappers, and even the unstable sands of the exercise-grounds ... supply [the criminal] 


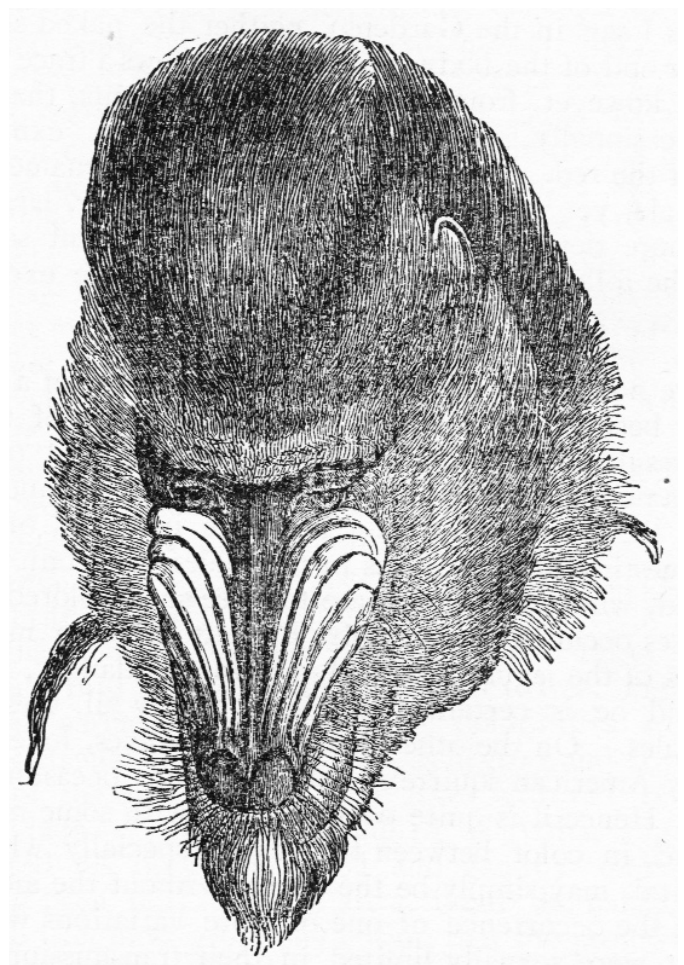

Fig. 3. The head of a gorilla whose facial markings Darwin compared with the bodily ornamentation of 'savages' (Charles Darwin, The Descent of Man, and edn (Amherst, NY, 1998), p. 557)

with a surface on which to imprint his thoughts and feelings' ${ }^{38}$ The criminals' urge to draw was called 'graphomania'. This pictographic excess resulted from their atavism, which forced them to communicate in the hieroglyphic and symbolic manner of primitives.

Darwin's work had also suggested the extension of physiognomy to encompass material culture. Darwin stretched a physiognomic interpretation of races beyond the body, and applied it to an extended field that included firstly tattoos and then clothing, but also art and architecture. In so doing he completely blurred the boundaries between ornaments on the body and ornaments beyond it. In the Descent of Man he elided any distinction between facial decorations and acquired physical characteristics:

As negroes and savages in many parts of the world paint their faces with red, blue, white, or black bars, - so the male mandrill of Africa appears to have acquired his deeply-furrowed and gaudily looking face from having been thus rendered attractive to the female. ${ }^{39}$

Both Darwin's and Lombroso's conception of ornament exceeded the limits of the body to encompass the body's material prostheses, its cultural products. Through a physiognomic reading that denied a distinction between the criminal body and its material prostheses, Loos moved from a condemnation of bodily ornamentation in the form of the tattoo to a condemnation of ornamentation in all functional realms of culture. 
ORNAMENT AND CRIME

Loos began his famous essay with Ernst von Haeckel's famous biogenetic principle, 'ontogeny recapitulates phylogeny'. Haeckel, one of the first popularizers in Germany of Darwin's theory of evolution, argued that the stages of an embryo's development correspond with the evolutionary development characteristic of its species. Loos summarized it succinctly:

In the womb the human embryo goes through all phases of development the animal kingdom has passed through. And when a human being is born, his sense impressions are like a new-born dog's. In childhood he goes through all changes corresponding to the stages in the development of humanity. At two he sees with the eyes of a Papuan, at four with those of a Germanic tribesman, at six of Socrates, at eight of Voltaire. ${ }^{40}$

He invoked Haeckel's mapping of the human developmental scale onto the evolutionary scale of the species as proof of the equivalence between children, women, primitives and criminals.

Criminal anthropologists seized on Haeckel's law to justify the crucial concept of atavism. Haeckel explained the existence of certain ornamental, superfluous traits (such as tails and redundant mammary glands in humans) as a result of latent heredity, atavismus. These traits, which according to the theory of natural selection should have disappeared, sometimes resurfaced in later generations. Haeckel explained these anomalies as instances of evolutionary regression, their parallel existence in ontogeny (for example, in a human embryo of one month) proving to him that they were remnants of a primitive form.

Nordau championed Haeckel and Lombroso in Vienna. He explained how, by using Haeckel's law, the anthropologist could catch a glimpse of primitive man in present-day children: 'According to the biological doctrine of evolution, ontogeny recapitulates phylogeny ... consequently, one can study children to determine the mentality of the species at the beginning of its evolution.' ${ }^{41}$ For Lombroso and Nordau, children, criminals and women represented an arrested development in which ornament flourished; they were modern-day embodiments that recalled primitive man. In 'Ornament and Crime', Haeckel's law was important not only because it placed modern, unornamented man in a privileged position vis-à-vis atavistic or primitive man, but also because it provided scientific justification for the superiority of 'modern' aesthetics.

When Loos wrote about ornament, he repeatedly turned to Haeckel's biogenetic principle and to Lombrosian concepts of criminality. These concepts appear consistently — in his writings throughout nearly three decades. Even when extolling peasant culture, as he did in 'Architecture', Loos based his arguments on criminal anthropology. Almost twenty years after 'Ornament and Crime', Loos returned to the theme of atavism in 'Ornament and Education' (1924). He again equated primitives with children. Education was of primary importance because, 'to educate someone is to help them leave their primeval condition. Every child has to repeat the development that took mankind thousands of years'. ${ }^{42}$ This development, once more, was marked by the disappearance of ornament from objects of daily use. 

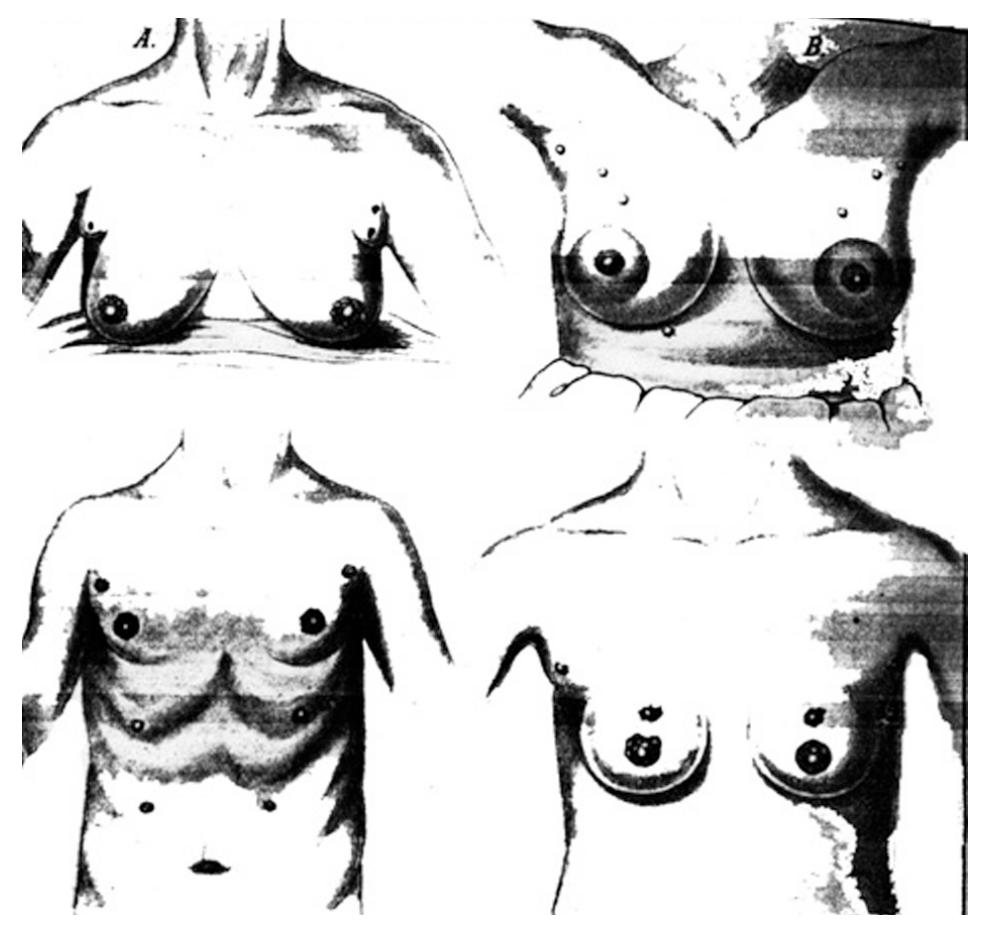

Fig. 4. Redundant mammary glands as examples of atavistic traits (Ernst Haeckel, The Evolution of Man: A Popular Scientific Study, I (London, 1905), p. 266)

ORNAMENT AND EVOLUTION: SEMPER AND RIEGL CONFRONT DARWIN

Loos wrote in the tradition of the nineteenth-century architectural historians Gottfried Semper and Alois Riegl, both of whom confronted the question of how art and ornament fit into the new evolutionary framework proposed by Darwin. For a number of years art historians joined with numerous scientists who resisted a purely materialist and mechanistic interpretation of material culture associated with the On the Origin of Species (1859). Semper and Riegl followed other critics of Darwin in claiming that the prevalence of ornament in nature disproved mechanistic conceptions of evolution. The prevalence of ornament in nature was so pertinent that in The Descent of Man and Selection in Relation to Sex (1871) Darwin emphasized his controversial theory of sexual selection in order to account for it. Despite the importance of this second book, the role of ornament in Darwinian evolution would remain (almost to this day) an obscure and forgotten aspect of natural selection.

After the appearance of On the Origin of Species the place of ornament in evolution moved to centre stage, not only in art history, but also within natural science. For a number of years Darwin and Alfred Russel Wallace, who shared most of Darwin's own views about the origin of the species, debated the existence of 'ornaments' that did not play functional roles. ${ }^{43}$ Critics of natural selection pointed out that the existence of ornament in nature escaped the strictly mechanistic processes ostensibly described by Darwin. They maintained that Darwin's theory could not account for 'ornament' in 
nature. It could not explain the abundance of colour in certain organisms or ornamental traits that would hurt, instead of improve, an organism's chance of survival, like the peacock's tail or the Hottentot's steatopyga (Darwin's example of an unusual protuberance in the posterior part of the body). The Duke of Argyll, one of the most popular writers on evolution, argued that natural selection could not explain beauty. ${ }^{44}$

Darwin responded to these objections in The Descent of Man. He acknowledged that 'mere physical conditions' could not account for ornamental traits, such as those 'beautiful and artistically coloured' caterpillars, birds, butterflies with 'gaudy plumage and ornaments', and the song of certain birds. He responded to the objection that natural selection stopped where ornament began by further developing his lesserknown theory of sexual selection. Darwin explained the anomaly of ornament by arguing that 'ornamental characters' were 'secondary sexual characters' used to attract the opposite sex. He thus accounted for natural elements clearly not determined by functional needs: ornament in nature, ranging from colour to song.

With sexual selection, Darwin confronted other explanations of ornament advanced by people in his own field (for example, Wallace). In order to explain how ornament arose independently of the need for survival posited by natural selection, he proposed the idea that ornament had no functional determinants. Even clothing, typically seen in utilitarian terms, might have been 'first made for ornament and not for warmth' ${ }^{45}$ Alois Riegl, known for his opposition to mechanistic theories of ornamentation, agreed.

Semper, the predominant architectural theorist of the mid-nineteenth-century Germany and Austria, held a theory of ornament that contrasted with that of natural selection. For him, architectural ornament emerged organically from a specific cultural milieu, as a representation of a building's inner structure. He identified a building's 'cladding' (Bekleidung) as the complement to a building's internal tectonic structure, but also as a crucial representation of that structure in aesthetic terms. In Semper's words, 'cladding' transformed 'the completely material, structural, and technical prototype that was the dwelling ... into monumental form, out of which arose true architecture' ${ }^{46}$ 'Cladding' was necessary to simultaneously conceal a building's inner structure and express that structure's ideal, original state; without cladding a building was merely the material it was made from, but cladding provided 'an external aesthetically palpable suggestion of what is invisibly there and represented' ${ }^{47}$ Semper correlated architectural cladding with clothing; as he wrote in Der Stil, 'almost all structural symbols ... are motives ... borrowed directly from the domain of costumes and, in particular, from its finery!'. ${ }^{48}$ Even tattoos, Semper claimed, could be derived from the position and functions of subcutaneous muscles. ${ }^{49}$ He did not, however, associate them with primitiveness.

In Der Stil, Semper did not confront the question of cultural evolution; written contemporaneously with Darwin, this work proposed a non-evolutionary classification system of fixed elements derived from the work of the French anatomist Georges Cuvier. ${ }^{50}$ In his later work, however, he was forced to explicitly confront the theory of natural selection, and refused to accept that it played a role in the development of architecture. Nevertheless, a complete denial of the role of ornament in evolutionary theory would not last long. Architectural theorists writing after Semper would no longer be able to escape the issue of ornament and natural selection. If ornament was 

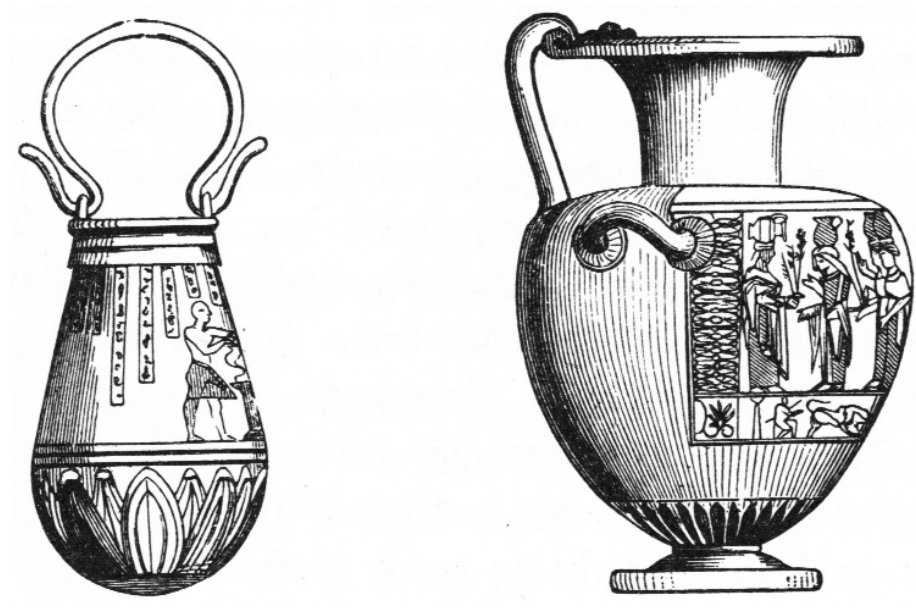

Fig. 5. Semper used these examples to show how a careful study of these pots could reveal the culture that created them (Gottfried Semper, Kleine Schriften (Berlin, 1884), p. 264)

linked with both culture and structure, did it therefore follow an evolutionary development akin to the one described by Darwin? Alois Riegl, Semper's successor as the most significant critic in Vienna, re-evaluated the role of ornament in an evolving world.

Echoing Darwin's critics, Riegl noticed how the evolution of ornament did not follow the strict, mechanistic development of natural selection. Writing after the publication and popularization of Darwin's On the Origin of Species and contemporaneously with Loos, he could not simply posit all architecture as unaffected by evolution, as Semper had done before him. Instead, Riegl regarded ornament as the one and only architectural element not governed by evolutionary forces. There 'unquestionably was a close and causal relationship between Darwinism and artistic materialism: the materialist interpretation of the origin of art is nothing other than Darwinism imposed upon an intellectual discipline'. ${ }^{51}$ His work represented a shift away from 'the materialist, scientific worldview, first promulgated by Lamarck and Goethe and subsequently brought to maturity by Darwin'.$^{52}$ Riegl correlated Semper's interpretation of artistic work on the basis of technologies and materials with Darwin's concept of natural selection, and contrasted both with his own, which invoked 'conscious, artistic invention' ${ }^{53}$

One of the key examples on which Riegl's re-reading of Semper turned was the tattoo, a reading first articulated in his review of a collection of Maori art brought to Vienna's Museum of Natural History in 1890. ${ }^{54}$ In Stilfragen (1893), he then reprinted images and examples taken from John Lubbock's famous The Origin of Civilisation and the Primitive Condition of Man. Lubbock, focusing on 'savage' ornaments and tattoos, popularized the idea that studies of peripheral cultures shed light on the origins of European civilization. For Riegl, the Maori were an isolated tribe, free from external influences, exemplifying the 'contemporary primitives' who were throwbacks to the ancestors of contemporary Europeans. Maori ornament was based on the spiral, which Semper interpreted as relating to the craft of textile spinning. The Maori, however, did not possess this technology. Thus Riegl argued that absolutely no causal relationship 

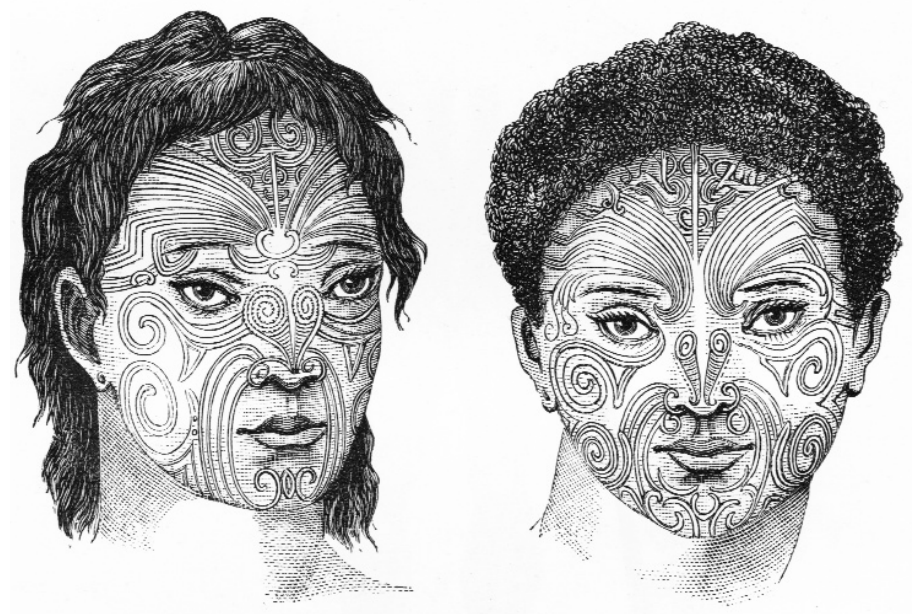

Fig. 6. Tattooed faces

(Originally from John Lubbock, The Origin of Civilisation and the Primitive Condition of Man (New York: D. Appleton, 1871), p. 47; as reprinted in Alois Riegl, Stilfragen: Grundlegungen zu einer Geschichte der Ornamentik (Berlin, 1893), p. 79)

existed between technology, structure, and ornament. The Maori's spirals were, he wrote, both carved out of wood and stone and tattooed on the skin, with neither process related to the spinning of textiles. ${ }^{55}$ Riegl argued that the practice of tattooing even 'preceded' that of wearing clothes. He underscored the indeterminacy of tattooing practices to support Riegl's thesis on the primacy of aesthetic drives over the accommodation of utilitarian needs. As he wrote in Stilfragen, 'the human desire to adorn the body is far more elementary than the desire to cover it ... the decorative motifs that satisfy the simple desire for adornment ... surely existed before textiles were used for physical protection' ${ }^{56}$

Riegl termed the fundamental aesthetic drive Kunstwollen, or 'artistic will'. In his account, Kunstwollen was revealed through those elements of architecture and applied art not determined by functional exigencies. In contrast to Semper, ornament thus became a mere trace of a cultural force, a trace not determined by its relation to any other part of the architectural ensemble. ${ }^{57}$ In Riegl the tattoo was explicitly presented as the ur-ornament, an ornament which provided no material protection for the body, and thus, as the product of a purely artistic drive: 'Do we not still encounter Polynesian tribes today who do without any form of clothing, while they tattoo their bodies from head to toe, thereby making full use of linear decorative techniques? ${ }^{258}$

The work of art or architectural historians such as Semper and Riegl converged with that of Darwin and other naturalists in that the architectures they described were primarily bodily. These conceptions of ornament bridged the animate and the inanimate, and crossed from private to public spheres. Loos continued to use the tattoo as a nexus between bodies and architectures, and continued to focus on the 'primitives' of New Guinea. He incorporated criminal anthropology into these traditions by defining ornament through its identity with the criminal and the primitive.

Loos's key contribution to architecture theory was to tie ornament directly to cultural evolution, a move which implied that every aspect of architecture and applied art was determined in the final instance by natural selection. This was precisely the move that his predecessors in architectural theory, such as Semper and 
Riegl, had resisted. Even Darwin fought against this in his later work. The basis for Loos's argument was Lombrosian criminal anthropology. In police work, all manner of signifiers, including those regarded as purely aesthetic in artistic or architectural terms, were related to levels of criminality. ${ }^{59}$ While artistic and architectural theories were based on the split between the purely aesthetic and the functional, according to Lombroso all cultural phenomena were functional, even if only as markers of cultural evolution. That which architectural theory attempted to disengage from the imperatives of evolution and establish as the product of pure aesthetic production, criminal anthropology took as itself a mark of evolutionary and criminal development.

\section{THE INCARCERATION OF PRIMITIVISM}

Loos's evolutionary view of architecture resurfaced when he was asked to design a building for the Mexican parliament. Instead of following his 'modern' logic, he turned to pre-Colombian architecture. There, he applied different principles than in Austria, since natural selection should have ensured that ornament would evolve out of existence in modern civilization. ${ }^{60}$ Modern ornament was an impostor in civilized cultures, a non-signifier through which one could no longer read the culture that produced it:

Because ornament is no longer organically linked with our culture, it is also no longer an expression of our culture. Ornament as created today has no connexion with us, has no human connexion at all, no connexion with the current world-order. ${ }^{61}$

Modern civilization, then, should therefore evolve in parallel with the disappearance of ornament from objects of daily use.

Loos did not, however, always oppose ornament. Rather it was the mélange of applied art, institutionalized in the Wiener Werkstätte, the Kunstgewerbeschule and the Deutscher Werkbund, which he abhorred. ${ }^{62}$ In fact, he not only tolerated but admired ornament in primitives. ${ }^{63}$ As the Papuans evolved, their ornaments would one day reach the level of the moderns, and become extinct: 'The Papuans can invent new ornaments, until they reach the total absence of ornamentation. ${ }^{64}$ The problem came when modern man tried to contrive a new ornament: 'I do not consider the invention of new ornaments as a new force, rather - in civilized man - it is a sign of degeneration. ${ }^{65}$

Loos preached the exclusion of ornament from the applied arts, but welcomed it in the 'pure' or fine arts, where the primitive Drang could run rampant. His acceptance of primitivism in the fine arts can particularly be seen in his relationship with the painter Oskar Kokoschka. As the historian Carl E. Schorske has noted, Loos's relationship with Kokoschka, 'symbolized a wholly new relationship between fine and applied art'. ${ }^{66}$ Yet even before Loos 'rescued' Kokoschka from painting women's fans and postcards, he had already theorized a profoundly different relationship between ornament, art and primitivism.

Loos criticized ornament only in modern Gebrauchsgegenstande, whilst he entirely accepted it in pure art. In an article criticizing the Deutscher Werkbund, Loos found a 




Fig. 7. Adolf Loos, Design for the Mexican parliament building (1923) (Giovanni

Denti and Silvia Peirone, Adolf Loos, opera completa (Rome, 1997), p. 204) 


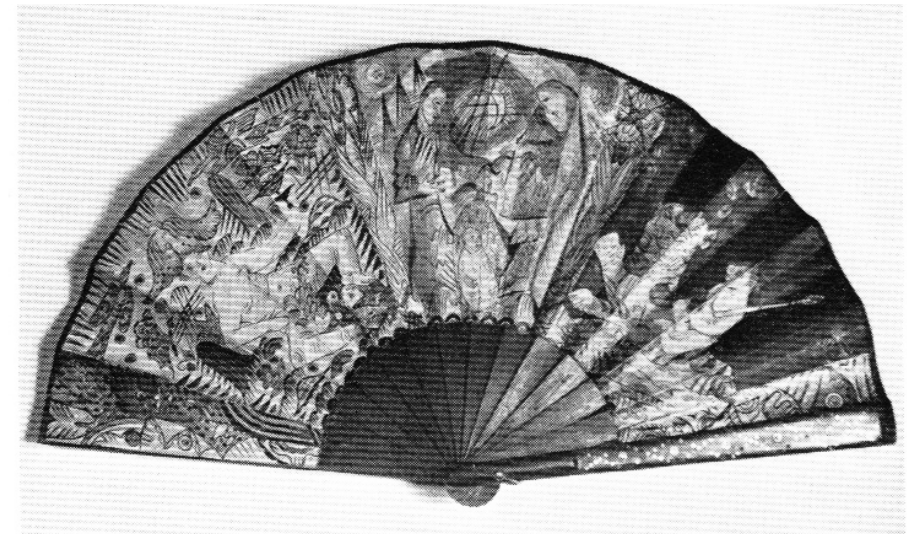

Fig. 8. An example of Kokoschka's lesser-known applied art. This painted fan was produced for the Wiener Werkstätte in 1909. It appeared revolutionary at the time because it was not decorated with traditional ornaments (Werner J. Schweiger, Der junge Kokoschka: Kunstgewerbeschule, Wiener Werkstätte, Cabaret Fledermaus, Kunstchau, 1908 (Vienna, 1983), p. 23)

place for art in his history of civilization qua history of the emancipation from ornaments in everyday objects. As a culture developed, Loos wrote, ornament disappeared from Gebrauchsgegenstande, but continued in the pure arts:

The ornament in every-day objects is the beginning of art. The black Papuan covers all of his utensils with ornaments. The history of humanity shows how art seeks to liberate itself from its profanation, emancipating itself from every-day objects, from the industrial product. $^{67}$

In 1906, the year in which Loos met Kokoschka, he explained - in an article appropriately titled 'Cultural Degeneration' -- that, 'overall, modern man considers the combination of art and every-day objects as the greatest humiliation' ${ }^{68}$ Impressed by Kokoschka's poster for the Art Exhibition, he promised to help him, but only if he left applied art.

The separation between applied and fine arts appeared in Loos's earliest work. In his criticism of the Kunstgewerbeschule, published in 1897, he wrote that, 'Applied to industry, even the best paintings offend ${ }^{\prime}{ }^{69}$ Furthermore, in the guidelines for the art administration which he later supported, the separation between applied and fine arts was enforced strictly. He insisted that the education of artists 'should be trusted to the School of Fine Arts and not the School of Applied Art'. ${ }^{70}$ The School of Applied Arts should never attempt to educate artists or sculptors, who should be trained exclusively in the fine arts tradition (architects requiring a completely different training).

For Loos the fine arts arose from the primitive, savage and erotic urge to ornament: 'The urge to decorate one's face and everything within reach is the origin of the fine arts. ${ }^{.71}$ In modern cultures, Loos wrote, 'art is the substitute for ornament ${ }^{\prime 2}{ }^{72}$ Ornament, he explained, 'because of its primitivism, comes close to $\operatorname{art}^{\prime} .{ }^{73}$ Because Loos did not permit either ornament or artistic intervention in objects of daily use, he trapped them within canvases. The fine arts were the only place where ornament could be lawfully used.

\section{CONCLUSION}

It is a truism that modern design and architecture were characterized by a thorough elimination of ornament. The question that we have attempted to broach here is what 
exactly became constituted as ornamental and why. A variety of discourses from evolutionary theory, natural history and criminal anthropology defined ornament in art and architectural theory. Slippages from physiognomies to Gebrauchsgegenstande revealed places where ornament was defined both scientifically and architecturally. These slippages, and the definitions of ornamentation produced by them, continued to affect architecture long after nineteenth-century criminology was abandoned.

Science and architecture converged in the concept of the tattoo, whose ambiguous status - on the body yet external to it - made it interstitial to both of these disciplines. Semper's, Riegl's and Loos's uses of the concept of tattoo revealed how theories of ornamentation were defined alongside discourses on tattooing used in evolutionary theory and criminal anthropology. Scientists and art historians investigated, at the same time, the physiognomy of the human body and of its material culture.

Specific references, dialogues and exchanges constituted the interstitial, prosthetic discourses which defined ornament. For example, both Semper and Riegl dealt explicitly with tattooing and with Darwin's concept of ornamentation; Riegl studied Maori art and reprinted images of tattooed 'primitives' published by John Lubbock; Loos referred to Max Nordau, employed the 'Italian School' of criminology's concept of tattoo, invoked Haeckel's 'ontogeny recapitulates phylogeny' law, and showed how atavism could explain retrograde architecture and design. Scientists were also vocal on matters of design and architecture. Darwin believed his evolutionary theory proved the superiority of Greek art and that coloured lines on a gorilla's face explained primitive tattooing practices; Haeckel explained ornament through atavism; and Lombroso analyzed criminal inscriptions, tattoos and pottery with the keen eye of an art historian. These connexions and cross-references all appear in the contested skins marked by ornament as feminine, primitive and criminal. More importantly, they show how primitives, criminals and women were, in turn, ornamentalized. While Darwin, Haeckel, Nordau and Lombroso defined ornament variously as primitive, sexual, monstrous, and criminal, Loos incorporated these discourses into aesthetic and architectural theory.

The separation of the fine arts from the applied arts that Loos defended was but one instance of the many boundaries of modern life that upheld the social order, managed deviance, and indelibly defined individual and collective subjectivities. The order represented by the museological spaces that were aptly the birthplace of Loos's theory, and the resulting incarceration of 'primitive' art within them, conspired as boundaries marking and managing participation in modernity.

Critiques of the modern architecture which Loos promoted have tended to be made on the basis of Marxist cultural theory, in which it is presented as an unwitting tool of either capitalist planning, or linguistic and literary theory, where it is seen as semantically impoverished or syntactically undefined. What has passed through the analytical grid of each of these critiques is the folding of modernist architecture within systems of discipline, control and incarceration based on politics of personal and social identity, an enmeshing which is typified in modern deployments of ornament.

The design of our most immediate objects of daily use - the saltshakers, wallets, underwear, and food products studied by Loos - was shaped by these interstitial 
discourses. The qualities of superfluous (Überflüssig), degenerate (Entartung) and criminal (Verbrechen) were identified with ornament simultaneously in natural history, medicine, criminal anthropology and architectural and aesthetic theory. In the late nineteenth century ornament became the preferred boundary between the normal and the pathological, and between the functional and the arbitrary, in art and architecture alike. Hence to the many virtues of modern design - such as functional, modern, useful, and lawful — we re-establish as essential (and not 'ornamental') its opposites in modern life: dysfunctional, primitive, useless and criminal.

\section{ACKNOWLEDGMENTS}

Jimena Canales wishes to thank Peder Anker, Eve Blau, Peter Galison, Jim Moore, Antoine Picon, Liza Zwiebach, the Minda de Gunzburg Center for European Studies at Harvard University, and the anonymous referees of Architectural History. All translations are by Jimena Canales.

\section{NOTES}

I The first publication of 'Ornament und Verbrechen' is unknown, but before it was published Adolf Loos presented lectures with that name, which he retrospectively dated to 1908. 'Ornament und Verbrechen' lectures were reported in Fremden Blatt, 22 January 1910, p. 21, and Der Sturm, 1, 3 March 1910, p. 8. French translations appeared in the Cahiers d'aujourd'hui (June 1913), and L'Esprit Nouveau, 2, 15 November 1920, pp. 159-68. It appeared in German in the Frankfurter Zeitung, 24 October 1929. Citations taken from Trotzdem (Innsbruck, 1931), pp. 79-92.

2 Le Corbusier's assessment was typical: in his forward to the publication of 'Ornement et Crime' in L'Esprit Nouveau, he wrote, 'Loos is one of the predecessors of the new spirit. Around 1900, when the enthusiasm for Jugendstil was high, in the time of excessive decor, Loos began his crusade against the redundancy of these tendencies'. Le Corbusier, L'Esprit Nouveau, 2 (1920), p. 159.

3 Friedrich Nietzsche, Unzeitgemässe Betrachtungen: Vom Nutzen und Nachtheil der Historie für das Leben, 2 (Leipzig, 1874; citation taken from 'On the Uses and Disadvantages of History for Life', in Untimely Meditations, ed. Daniel Breazeale, trans. R. J. Hollingdale (Cambridge, 1997), pp. 58-123 (p. 123)).

4 Amongst those who notice a homology between Loos's reading of tattoos and the work of Cesare Lombroso, but who have not analyzed Loos's actual connexions and debt to criminal anthropology are: Stephan Oettermann, Zeichen auf der Haut: Die Geschichte der Tätowierung in Europa (Frankfurt, 1979), pp. 64-65; Hildegund Amanhauser, Untersuchungen zu den Schriften von Adolf Loos (Vienna, 1985), p. 29; Mark Anderson, Kafka's Clothes: Ornament and Aestheticism in the Habsburg Fin de Siecle (Oxford, 1992), pp. 180-82; Michael R. Peplow, 'Adolf Loos: Die Verwefung des wilden Ornaments', in Ornament und Geschichte: Studien zum Strukturwandel des Ornaments in der Moderne, ed. Ursula Franke and Heinz Paetzold (Bonn, 1996), pp. 173-89 (pp. 178-79); George L. Hersey, The Evolution of Allure: Sexual Selection from the Medici Venus to the Incredible Hulk (Cambridge, 1996), p. 123; and Hubert Damisch, 'L'Autre "Ich", L'Autriche-Austria, or the Desire for the Void: Toward a Tomb for Adolf Loos', Grey Room, 1 (Fall 200o), pp. 26-41 (p. 40, n. 14). For contemporary interpretations of Loos's views on ornament, see Juan José Lahuerta, 'Reclamación: Nota a favor del ornamento', Architectura Viva, 87, pp. 23-25, and the various essays in Crime and Ornament: The Arts and Popular Culture in the Shadow of Adolf Loos, ed. Bernie Miller and Melony Ward (Toronto, 2002). For Loos's theory of ornament in historical context, see María Ocón Fernandez, Ornament und Moderne: Theoriebildung und Ornamentdebatte im deutschen Architekturdiskurs (1850-1930) (Berlin, 2004).

5 Loos, Ins leere gesprochen (Paris and Zurich, 1921). The attribution of first 'battle cry against ornament' appeared in a note to the 1932 edition of Ins leere gesprochen (Innsbruck, 1932).

6 It is important to note that Loos focused on the acanthus motif, whose significance in art theory can be traced back to Vitruvius. 
7 Loos, 'Das Luxusfuhrwerk', Neue Freie Presse, 3 July 1898; citations taken from Sämtliche Schriften, ed. Franz Glück (Vienna, 1962), 1, pp. 62-69 (p. 65).

8 Loos, 'Das Luxusfuhrwerk', p. 69.

9 For a criticism of the neglect of the role of taste in work on Darwin's, see Evelleen Richards, 'Darwin and the Descent of Woman', in The Wider Domain of Evolutionary Thought, ed. David Oldroyd and Ian Langham (Dordrecht, 1983), pp. 57-111.

10 Nevertheless, Darwin cautioned how 'there is no evidence in favor of this belief'. Charles Darwin, The Descent of Man, and Selection in Relation to Sex (London, 1871; citations taken from 2nd edn, Amherst, NY, 1998), p. 605.

11 Darwin, The Descent of Man, p. 603.

12 For recent studies on Darwin and the visual arts, see 'The Darwin Effect: Evolution and NineteenthCentury Visual Culture', Nineteenth-Century Art Worldwide, ed. Linda Nochlin and Martha Lucy, 2 (2003), and David Kohn, 'The Aesthetic Construction of Darwin's Theory', in The Elusive Synthesis: Aesthetics and Science, ed. Alfred I. Tauber (Dordrecht, 1996), pp. 13-48.

13 Loos, 'Damenmode', Neue Freie Presse, 21 August 1898. Republished in Dokumente der Frauen, 6. 23, 1 March 1902, pp. 660-61. Citations taken from Sämtliche Schriften, 1, pp. 157-64 (p. 161).

14 For perceptions of New Guinea at the time, see Janet Stewart, Fashioning Vienna: Adolf Loos's Cultural Criticism (London, 2002).

15 Although due to their lower development, it was acceptable - and even desirable - for women to dress in the style of prostitutes, it was unacceptable for anybody else to do so. References to prostitutes as embodiments of arrested development abound in Loos's work. As early as 1897, Loos insulted the Lefler room at the Christmas exhibition of the Austrian Museum by saying it was worthy of a 'cocotte'. Loos, 'Weihnachtsausstellung im Österreichischen Museum', Die Zeit, Vienna, 13. 168, 18 December 1897, p. 186. Citation taken from Loos, Escritos I, ed. Adolf Opel and Josep Quetglas, trans. Alberto Estévez, Josep Quetglas and Miquel Vila (Madrid, 1993), pp. 21-27 (p. 27).

16 Loos, 'Damenmode', p. 159.

17 Loos, 'Damenmode', p. 159. Proof for the latter trend was 'that just now the number of court cases involving crimes against children is increasing in the most frightful way'. In 1928 Loos was arrested for allegedly soliciting sex from minors.

18 Loos, 'Ornament und Erziehung', Wohnungskultur, 2-3 (1924), p. 81. Citation taken from Trotzdem (Innsbruck, 1931), pp. 200-07 (p. 205).

is Loos, Wohnungswanderungen (1907). Partially republished in Loos, 'Wohnungs-Moden', Frankfurter Zeitung, 8 December 1907. Citations taken from Die Potemkin'sche Stadt: Verschollene Schriften 1897-1933 (Vienna, 1983), pp. 106-15. Loos finished his ostensibly ornament-free 'Café Museum' in 1907.

20 Loos, Wohnungswanderungen, p. 108. When compared to 'orientals', Loos particularly worried that Austria was falling behind Japan with respect to its cultural level. See Loos, 'Die Plumber', Neue Freie Presse, 17 July 1898. 21 Loos, Wohnungswanderungen, p. 108.

22 Loos, 'Ornament und Verbrechen', p. 8o. Italics original.

23 Throughout the late nineteenth century Lombroso's criminology passed through various stages of popularity. Although at the third international congress of criminal anthropology (1893) Lombrosian anthropology suffered a marked setback from the attack of the 'French school' of criminology, it nevertheless remained extremely influential well into the twentieth century.

24 Lombroso's work was a key influence to the 'Viennese school' of criminal anthropology associated with Moritz Benedikt, who sought the origins of in criminality in the brain. Cesare Lombroso, L'Uomo Delinquente (Milan, 1876; citations taken from 4th edn, Turin, 1889). Translated into German as Lombroso, Der Verbrecher, in anthropoligischer, ärztlicher und juristischer Bezeihung (Hamburg, 1887-90). For Moritz Benedikt, see Die Wiener Schule und die Criminal Anthropologie (Vienna, 1902). On the relationship between Benedikt and Lombroso, see Mariacarla Gadesbusch Bondio, Die Rezeption der kriminalanthropologischen Theorien von Cesare Lombroso in Deutschland von 1880-1914 (Husum, 1995), pp. 129-31.

25 Loos's private correspondence contains references to the work of Richard von Krafft-Ebing, author of Psychopathia Sexualis (Stuttgart, 1886). See Loos to Karl Kraus, n.d., Semmering, Germany, Wiener Stadt- und Landesbibliothek, 138833. For references to Nordau, see Loos, Presentation Card, Wiener Stadt- und Landesbibliothek, $138830 / 2$.

26 The Austrian explorer Andreas Reischek furnished the Naturhistorisches Museum in Vienna with 
Maori art. In 1907, the year of Loos's first reference to tattoos, the Viennese ethnologist Rudolf Pöch, began to publish the results of his explorations in New Guinea and disseminate in the Viennese press the image of the tattooed Papuan. Rudolf Pöch, 'Einige bemerkenswerte Ethnologika aus Neu-Guinea', Mitteilungen der Anthropologischen Gesellschaft in Wien, 37 (1907), pp. 57-71. This publication was preceded by Rudolf Virchow's work on tattoos. Other scientists who focused on New Guinea tattoos included R. E. Guise, 'On the Tribes Inhabiting the Mouth of the Wanigela River, New Guinea', Journal of the Royal Anthropological Institute, 29 (1899), pp. 205-19, and Francis R. Barton, 'Tattooing in South Eastern New Guinea', Journal of the Royal Anthropological Institute, 48 (1918), pp. 22-79. For recent work on tattoos in New Guinea, see Alfred Gell, Wrapping in Images: Tattooing in Polynesia (Oxford: Clarendon Press, 1993); Nicholas Thomas 'Marked Men', Art Asia Pacific, 13 (1997), pp. 66-73; and Christopher Wright 'Supple Bodies: The Papua New Guinea Photographs of Captain Francis R. Barton, 1899-1907', in Photography's Other Histories, ed. Christopher Pinney and Nicolas Peterson (Durham, NC, 2003), pp. 146-69. For a general history of tattooing, see Written on the Body: The Tattoo in European and American History, ed. Jane Caplan (London, 2000).

27 Kant compared architectural ornament to the tattooing of a New Zealander, each constituting an extraneous supplement to a purposefully-arranged form. Immanuel Kant, Critik der Urtheilskraft (Berlin, 1790; citation taken from Critique of Judgement, trans. Werner S. Pluhar (Indianapolis, 1987)), p. 77.

28 'Not one great country can be named ... in which the aborigines do not tattoo themselves. This practice was followed by the Jews of old, and by the ancient Britons.' Darwin, The Descent of Man, p. 595.

29 Darwin, The Descent of Man, p. 606.

3o See Ernst Grosse, The Beginnings of Art (New York, 1897), pp. 53-54.

31 The main authors linking tattoos and primitives were Mantegazza, Lubbock, Darwin and Scherzer. Both Darwin and Lombroso read Mantegazza and Lubbock on tattoos. For Darwin's references to Mantegazza and Lubbock, see Darwin, The Descent of Man, p. 594, n. 42.

32 Authors on the tattoos of criminals were Lacassagne, Magitot, Tardieu, Berchon, Parent-Duchatelet, Marro, Boselli and Salillas. The study of tattoos was not limited to the anthropological or criminal perspective. Other authors studied tattoos in history, noticing a proclivity for tattoos in ancient and medieval peoples (Ewald, Isidoro, Cesare, Luciano), and yet others focused on the use of tattoos by the insane.

33 `Ma la prima, principalissima cause della difusione di questo [tattuaggio] uso fra noi, io credo sia l'atavismo, o quell'altra specie di atavismo storico, che è la tradizione, comechè il tatuaggio sia uno dei caratteri speciali dell'uomo primitivo, e di quello in istato di selvatichezza.' Cesare Lombroso, L'Uomo Delinquente, p. 319.

34 Loos, 'Ornament und Verbrechen', pp. 79-80.

35 Loos, 'Ornament und Verbrechen', p. 80.

36 Loos, 'Ornament und Verbrechen', p. 80.

37 Both Loos and Nordau focused on the use of the colour violet in art as a mark of evolutionary development. According to Nordau 'the violet pictures of Manet and his school' were signs of the physical degeneration of the nervous system of the artists. For Loos, the use of violet entered art in the eighteenth century, when the evolutionary development of man corresponded to that of an eight-year-old child. Loos, 'Ornament und Verbrechen', p. 79.

38 Lombroso, Palimsesti del Carcere (Turin, 1888; citation taken from Florence, 1996), p. 37.

39 Darwin, The Descent of Man, p. 560.

40 Loos, 'Ornament und Verbrechen', p. 79.

41 Nordau, 'Nouvelle Théorie Biologique du Crime', La Revue, 42 (1902), pp. 150-64 (p. 153). Max Nordau's view of the criminal differed from Lombroso's in some minor respects. For example, Nordau was responsible for describing the habitual criminal as parasitic and not only atavistic. Overall, however, the similarities between the two criminologists were more overwhelming than the differences. In Nordau's words: 'Je suis heureux de constater qu'au fond, mon illustre maître et ami M. Lombroso et moi, nous sommes tout à fait d'accord.' See their 'debate' in Lombroso and Nordau, 'Parasitisme ou Atavisme', La Revue, 43 (1902), pp. $456-60$ (p. 459).

42 Loos, 'Ornament und Erziehung', p. 200.

43 Darwin to A. R. Wallace (Down, 28 May?] 1864), pp. 271-73; Darwin to Wallace (Down, 22 February 1867?), pp. 274-75; Darwin to Wallace (Down, 23 February 1867), p. 275; Darwin to Wallace (Down, 26 February 1867), pp. 276-77; Darwin to Wallace (Down, March 1867), pp. 277-78; Darwin to F. Müller (Down, 
22 February 1869?), pp. 292-93; Darwin to Wallace (Down, 16 March 1871), pp. 317-20. In Darwin, The Life and Letters of Charles Darwin, Including an Autobiographical Chapter, ed. Francis Darwin, 2 (New York, 1887; citations taken from New York, 1911).

44 Argyll, Reign of Law (London, 1860).

45 Darwin, The Descent of Man, p. 594.

46 Gottfried Semper, Der Stil in den technischen und tektonischen Künsten oder praktische Ästhetik: Ein Handbook für Techniker, Künstler und Kunstfreunde, 2 vols (Frankfurt, 1860, 1863), trans. Henry Mallgrave and Wolfgang Herrmann as 'Style in the Technical and Tectonic Arts or Practical Aesthetics: A Handbook for Technicians, Artists, and Patrons of Art', in Semper, The Four Elements of Architecture and Other Writings (Cambridge, 1989), pp. 181-263 (p. 255).

47 Semper, Der Stil, pp. 216-17.

48 Semper, Der Stil, p. 241.

49 'Some cultures actually have a correct knowledge of the position and functions of muscles which are covered by the skin, so that these activities on the surface of the skin could in a similar way be represented, or could be represented even more through graphic linearity; because of this it appears that the ornament of these cultures is already conceived in a structural-symbolic sense.' Semper, Der Stil, pp. 97-98.

50 Semper is known to have held Cuvier's work in high esteem. His first written reference to Darwin appeared in 1869. See Mallgrave, Gottfried Semper: Architect of the Nineteenth Century (New Haven, CT, 1996), p. 305, and Mallgrave, 'Introduction', in The Four Elements of Architecture and Other Writings (Cambridge, 1989), pp. 1-44 (pp. 30-32). On Semper's anthropological sources, see Joseph Rykwert, 'Semper and the Conception of Style', in Gottfried Semper und die Mitte des 19. Jahrhunderts, ed. Eva Börsch Supan (Zurich, 1974), pp. 67-81.

51 Alois Riegl, Stilfragen: Grundlegungen zu einer Geschichte der Ornamentik (Berlin 1893; citations taken from Problems of Style: Foundations for a History of Ornament, trans. Evelyn Kain, Princeton, 1992), p. 4.

52 Riegl, Problems of Style, p. 21.

53 While Riegl denied a materialist interpretation of art, he still believed that there was some correlation between ornament and culture. Riegl speculated that the need for ornament could die out altogether in some distant time, leaving functional objects plain and unadorned; until that time, however, he recommended that designers employ historical ornament, rather than invent ornaments anew or copy from nature. Riegl, 'Das Moderne in der Kunst', Graphische Kunst, 22 (1899), pp. 9-12 (p. 12). In Stilfragen, he argued that 'if, following the spirit of today's natural science, we are justified in assuming that contemporary primitive cultures are the rudimentary survivors of the human race from earlier cultural periods then their geometric ornament must represent an earlier phase of development in the decorative arts and is therefore of great historical significance'. Yet ornament could not be a precise index of cultural development because 'the mimetic impulse is so powerful that there is no stopping less talented cultures from borrowing from those with more ability.' Riegl, Problems of Style, pp. 16, 21, 22. Otto Wagner also grouped Semper and Darwin together in Moderne Architektur (Vienna, 1902), p. 93.

54 Riegl, 'Über neuseeländische Ornamentik', Mitteilungen der Anthropologischen Gesellschaft in Wien, 20 (1890), pp. $84-87$.

55 This argument was reiterated in Riegl, Problems of Style, pp. 77-78.

56 Riegl, Problems of Style, p. 5.

57 Riegl claimed that this aesthetic conception of ornament was present - yet ignored — in Semper's examples, especially those on tattoos:

it is the urge to decorate that is one of the most elementary of human drives, more elementary than the need to protect the body. This is not the first time such a proposition has been made; Semper himself expressed it several times. It is thus even more difficult to understand why, in the face of all this evidence, the origin of creative activity is still believed to postdate the invention of the techniques used to create protection for the body.

Riegl, Problems of Style, p. 31.

58 Riegl, Problems of Style, pp. 31-32.

59 In 1898 Vienna, Kamillo Windt implemented the prison system of the famous French criminologist Alphonse Bertillon after studying with him in Paris. For his work on fingerprinting, see Kamillo Windt, Daktyloskopie; Verwertung von Fingerabdrucken zu Identifizierungszwecken (Vienna, 1904); Windt and Siegmund Kodicek, Daktyloskopie, verwertung von Fingerabdrücken zu identifizierungszwecken; Lehrbuch zum selbstunterricht für Richter, Polizeiorgane, Strafanstaltsbeamte, Gendarmen etc., 2nd edn (Vienna, 1923). 
6o Loos believed that 'every implement [object of daily use] can tell something about the customs and characters of a people'. He learned this lesson from Semper, who believed that 'by looking at the pots that a certain people produced, we are able to tell in a general way what kind of race they were and how advanced their civilization was' (Loos, 'Glas und Ton', Neue Freie Presse, 26 June 1898; citation taken from Sämtliche Schriften, 1, pp. 55-61 (p. 55)). In Loos, the reading of cultures from their products was taken to a further extreme. He wrote: 'even if the only object that survived from a town which disappeared was a button, I could, by its form, deduce the clothing and customs of that town, their morals, religion, their art and spirituality.' According to Loos legitimate ornaments were signifiers through which the culture of a people and their level of civilization could be read (Loos, 'Antworten auf Fragen aus dem Publikum', Neues 8 UhrBlatt, 21 June, 9, 16, 23 August, 20 September, 4, 18 October 1919; citations taken from Loos, Escritos II, ed. Adolf Opel and Josep Quetglas, trans. Alberto Estévez, Josep Quetglas and Miquel Vila (Madrid, 1993), pp. $132-56$ (p. 145)).

61 Loos, 'Ornament und Verbrechen', p. 86. Loos's evolutionary thesis of ornament had consequences for theories of language, and he adamantly condemned artificial languages. According to him, language, like ornament-use, was 'organically connected' to a specific cultural level. Primitive cultures could not become modern simply by rejecting ornament or adopting a more advanced language; this process could not be forced. Language, architecture and fashion had to evolve naturally: 'Modern clothing is not enough. One should also have modern customs and speak modern German. If not, the effect is the same as the black soldiers in Central Africa, who take themselves for moderns simply because they wear hats.' Loos, 'Antworten auf Fragen aus dem Publikum', p. 132.

Loos compared modern ornament to modern artificial languages, in particular Volapük and Esperanto. When he commented on Otto Wagner's turn to the ornamentation of the 'Belgian school' in his creation of a train station, Loos described it as an unfortunate move away from 'the formal language of antiquity' towards a 'personal language' which he compared to 'an extravagant Volapük'. According to him, the crises of ornament and architecture arose because modern architects tried to speak in an artificial language. 'Modern architects', Loos wrote, 'resemble Esperantoists.' In his criticism of artificial languages, Loos was working in the tradition of earlier German linguists, such as Herder, who believed there was an inseparable and natural connexion between language, culture and evolutionary development that could not be artificially altered. For Loos on artificial languages, see Loos, 'Otto Wagner', Reichspost, 13 July 1911; on Esperantoists, see Loos, 'Ornament und Erziehung', p. 205. This line was erased in the version reprinted in Loos, 'Ornament and Education', in Ornament and Crime: Selected Essays, trans. Michael Mitchel (Riverside, Ca., 1998). For other allusions to language, see Loos, Foreword to Ins leere gesprochen; Loos, 'Antworten auf Fragen aus dem Publikum'; Loos, 'Die Emanzipation des Judentums', 1900, published for the first time in Loos, Escritos I, p. 251; 'Loos, Arnold Schönberg und seine Zeitgenossen', Anbruch (August and September 1924).

62 It is probable that many of his criticisms were also directed against Dagobert Peche, although he did not mention him by name. See Sabine Plakolm-Forsthuber, 'Dagobert Peche and "the Viennese Women's Crafts"', in Dagobert Peche and the Wiener Werkstätte, ed. Peter Noever (Vienna, 1998), pp. 79-95.

63 In this respect Loos has been widely misread, being categorically known as 'der Ornamentenfiend'. Even the essay 'Ornament and Crime' was translated as 'Ornament is Crime' in the French and Spanish versions. Later in his life Loos lamented about how the 'wrong interpretation' of his teachings was taken up by the 'neue Sachlichkeit' of the Weimar Bauhaus. 'Adolf Loos über Josef Hoffmann', Das neue Frankfurt (February 1931); reprinted in Loos, 'Modern angezogen', Prager Presse, 19 March 1931. Citations taken from Escritos II, pp. $284-85$ (p. 285). Loos differed from other enemies of ornament, such as the American Louis Sullivan, because behind his theory of ornamentation stood a stark scientific structure. He also distanced himself from the unornamented work of Joseph Hoffmann, where 'all that was superficial, in truth, his lack of ornaments, both past and present ... was really only an ornament' (Loos, Über Joseph Hoffmann (1931; published for the first time in Escritos II), pp. 282-83 (p. 283)). The term 'der Ornamentenfiend' referring to Loos appeared in Der Sturm, 6, 7 April 1910, p. 44 .

64 Loos, 'Otto Wagner', Reichspost, 13 July 1911; citation taken from Escritos II, pp. 37-42 (p. 41).

65 Loos, 'Otto Wagner', p. 41.

66 Carl E. Schorske, Fin-de-siècle Vienna: Politics and Culture (New York, 1981), pp. 338-39.

67 Loos, 'Die Überflüssigen', März, 15, 3 August 1908, p. 185; citation taken from Trotzdem, 2nd edn (Innsbruck, 1931), pp. 70-73 (p. 72). 
68 Loos, 'Kulturentartung', Trotzdem (Innsbruck, 1931), pp. 74-78 (p. 78).

69 Loos, 'Unsere Kunstgewerbeschule', Die Zeit, 13. 161, 31 October 1897, p. 78; citation taken from Escritos I, pp. 11-15 (p. 14).

70 Loos, Richtlinien für ein Kunstamt (Vienna, 1919; citations taken from Die Potemkin'sche Stadt: Verschollene Schriften 1897-1933, Vienna, 1983), pp. 148-66 (p. 157). Separata from Der Friede, 29 March 1919.

71 Loos, 'Ornament und Verbrechen', p. 80.

72 Loos, 'Ornament und Verbrechen', p. 91.

73 Loos, 'Ornament und Erziehung', p. 203. 